\title{
How Canadians decide What to Do
}

\author{
from our Special Correspondent recently in Canada
}

CANADA's attempts to devise effective planning machinery for science do not yet seem to have influenced the direction of public policy. Neither the Science Council nor the Science Secretariat was behind the recent decisions to cancel the intense neutron generator and the 150 inch Queen Elizabeth Telescope, which is as much a criticism of the organizations as it is of the decisions. Although neither organization is more than four years old, there is already talk of the need to reorganize them-the fact that $\mathbf{M r}$ Pierre Trudeau is said to take a particular interest in science policy has lent respectability to the rumours.

The Science Secretariat is the older of the two bodies. It was set up four years ago under the direction of Professor Frank Forward, as part of the Privy Council Office in Ottawa. Dr J. R. Weir, the present director, describes the secretariat as "the focal point for scientific advice within the government". It is also responsible for most of the gathering of information which goes into the development of policy, and recommending the kind of organization Canadian science needs. Dr Weir describes it as defining "the place of science and technology in Canada's total policy".

It is no coincidence that Dr O. M. Solandt, chairman of the Science Council, would describe his own job in almost exactly the same terms. Indeed, it is at times difficult to tell where one organization takes over from the other. Although the Science Council is less closely involved with the Government, it too takes a general view of its responsibilities. Dr Solandt says that the council's task is to "get government scientists to take a broad national view". The council, with twentynine members, meets several times a year, and has produced reports on space programmes for Canada and the intense neutron generator. Later in the year, the council is expected to produce a review which will recommend priorities on which Canadian science policies should be based. It is expected that this report will emphasize distinctly Canadian interests at the expense of research which could be carried out anywhere in the world.

Until this report is published, judgment of the Science Council's work is difficult, but it has come under fire in the pages of Science Forum, a new and lively journal devoted to Canadian science. Dr L. E. Howlett, head of the Division of Applied Physics at the National Research Council, criticizes the Science Council principally for its method of operation. "It is not entirely clear how surveys of what is and has been going on in science can form a sufficient basis for determining future scientific needs." It would be better, Dr Howlett says, for the Science Council to establish how best to stimulate Canada's economic development, and then to define a scientific policy which would support this development. The general report expected in December could go some way towards satisfying this aim; Dr R. Gaudry, rector of the University of Montreal and vice-chairman of the Science Council, hints that the report will recom- mend limitations on the scale of government expenditure on science, with the emphasis on areas unique to Canada. "It means pulling out of other areas where we couldn't compete with the giants," he says.

More criticism of the Science Council seems likely to be meted out when the Senate Committce on Science Policy continues its examination of Canadian science later this month. The committee was set up in March this year at the instigation of Senator M. Lamontagne, who is now its chairman. The committee, roughly equivalent to the House of Commons Select Committee on Science and Technology, is the first public forum for the discussion of science policy in Canada. Although the Senate ranks no higher in influence than the British House of Lords, the committee has made a good start. Senator M. Lamontagne, a professor of economics at the University of Ottawa, is a coherent critic of government policy. The Government, he says, is not spending enough on research-only 1.5 per cent of Canada's GNP, less than other industrialized countries. What is spent is spread too thin, and there are serious gaps in life sciences, medicine and social sciences. He would like to see the formation of a Ministry for Science. "We did it for culture," he says,

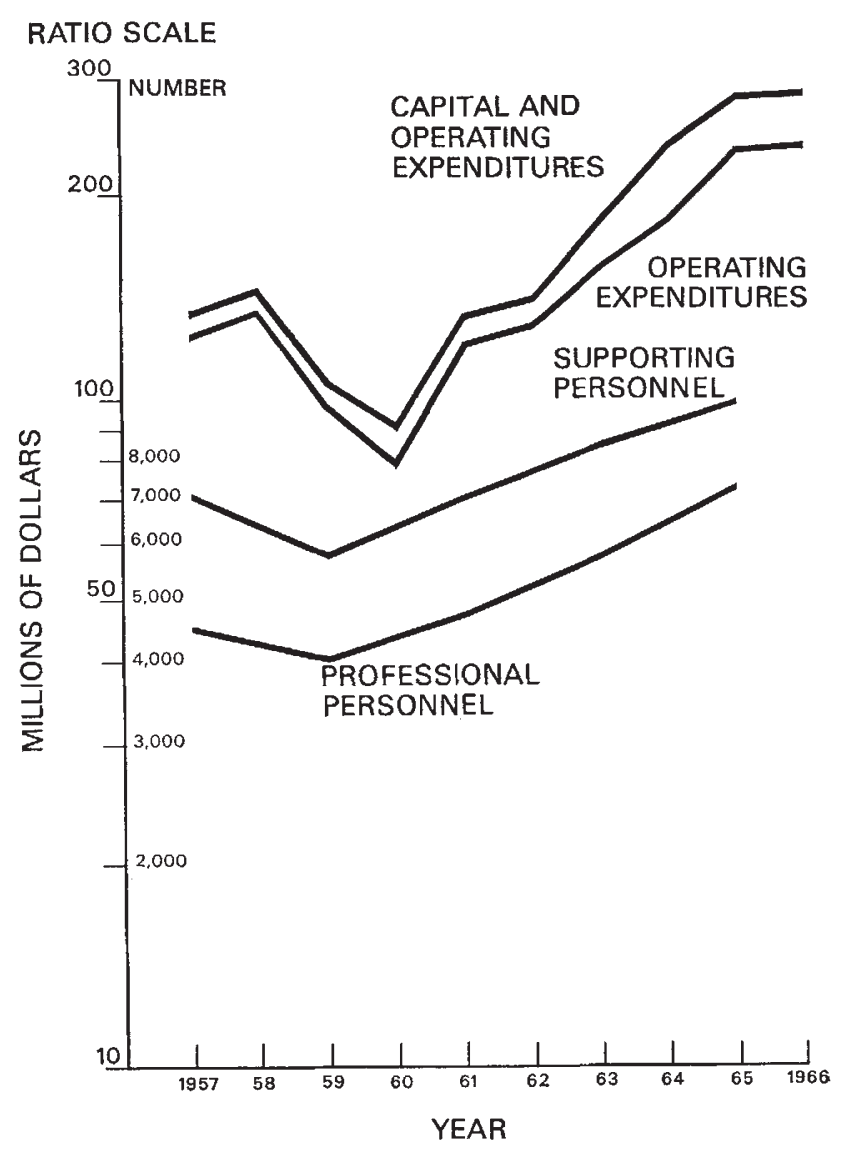

Growth of Canadian industrial research and development. 
"why not for science?" Senator Lamontagne also believes that Canada should establish three major centres, for life sciences, social sciences and physical sciences, as well as smaller centres devoted to specific problems. His committee, 18 strong and supported by two research directors, will be spending about two days a week discussing science policy, but is not likely to produce a report for at least another year.

Although Senator Lamontagne's recipe for a ministry of science and a triumvirate of research organizations has some elegance, its relevance to Canada's problems is doubtful. Like Britain, Canada needs particularly to spread an awareness of science throughout the civil service, not best done by bottling up scientific expertise in one ministry. There is, however, no doubt that changes are in the air, and one idea which is sometimes heard in Ottawa is that the Science Secretariat should be divided into two. The part responsible for direct advice to the Government would remain within the Privy Council, while the part responsible for investigations would move to the Science Council. At the moment the secretariat supplies advice to the Government as well as carrying out studies for the Science Council, an ambiguous position criticized by members of Senator Lamontagne's committee.

Although there is argument about the organization of science in Canada, there is a wide measure of agreement about what its aims should be. Industry must be persuaded to invest more in research. Because Canadian industry is dominated by foreign interests, very little research is done by Canadian firms. Although Canadians would like to reduce the amount of American influence, there is little hope that this can be done rapidly. Without the inflow of capital through foreign investment, Canada would be running a balance of payments deficit. In this situation, the Hon. C. M. Drury, president of the Treasury Board, see the choice as one between foreign investment or a slow growth rate. But while he believes that foreign ownership is becoming less significant as an issue because of the growth in competence of the local management, others disagree. Dr Solandt says that the slow growth of industrial research is "partly apathy", but that foreign ownership is a more important restraint. Dr John Orr, industrial adviser at the Department of Industry, points out that industry carries out only 41 per cent of the total research in Canada. "It should be nearer fifty or sixty per cent," he says. In 1965, the last year for which figures are available, 800 firms spent a total of $\$ 287$ million, and thirteen firms accounted for half of this figure. Although accurate figures are not available, $\mathrm{Mr}$ Orr's guess is that Canada spent as much again importing technology from abroad.

$\mathrm{Mr}$ Orr gives three reasons for this failure. Canada has little secondary industry, and the primary industry is resource based, with little tradition of technological involvement. The population of Canada, only twenty million people, means that the market is too small to support many large firms, which tend to do more research. Finally, he agrees that foreign ownership is very important-“"Canada is a horrible example of how far foreign ownership and control can go in the absence of Government efforts". To counter this trend, a whole series of inducements have been provided to encourage industry to do more research. The National Research Council, for instance, runs a programme called the industrial research assistance programme (IRAP) in which the salaries of new research workers in industry are paid by NRC. The programme does not apply to existing workers, and companies therefore only receive a benefit when they increase the scale of their research effort. The Department of Industry runs two schemes, called the Industrial Research and Development Investment Assistance, and the Programme for Industrial Technology (IRDIA and PAIT).

The Department of Industry programmes provide for assistance both for current expenditure and capital expenditure. In effect, the assistance amounts to 25 per cent of the cost of any new capital expenditure, and 25 per cent of the increase in current expenditure, based on the average of the last five years. Mr Orr says that so far 500 applications for these assistance programmes have been received, amounting to some $\$ 35$ million, 12 per cent of total industrial research expenditure. So far, the department has been concentrating on increasing the quantity of research rather than its quality, and has made few attempts to measure whether the investment has been a sound one. But early results on PAIT have encouraged the department; of eighteen projects which are now either terminated or completed, twelve are deseribed as successful. The industries concerned have projected sales in the first five years of products resulting from the programmes of $\$ 50$ million. The Government contribution to these eighteen programmes was a mere $\$ 1$ million, so the returns seem healthy enough if the sales justify the present optimism.

Despite this, it is very hard to find industrialists who approve of the assistance programmes. Many research directors agree that the assistance for current expenditures takes so long to be worked out and paid that it is hardly worth the trouble. The assistance for capital expenditure is better, because it can be used effectively as a means of persuading managements to make new investment in research. Another drawback from industry's point of view is that if the development is profitable, the grant must be repaid to the department. One engineer suggested that this makes it possible for industries to claim assistance at the last minute and only on those projects which are obviously going to be unsuccessful. The department also makes the stipulation that results of research must be applied in Canada, another requirement which industrialists find irritating. This may help to explain why British companies with subsidiaries in Canada have been slow in taking advantage of the assistance programmesMr Orr says that American companies have been much more eager. Professor Gaudry is contemptuous of the PAIT programme-_"The Government shares the cost only if the results are unexportable. This is unacceptable to 80 per cent of Canadian companies." The fact that the programmes are based on the quantity of research, and take no account of the quality, he describes as "very wrong and short-sighted".

Most people agree that more will have to be done before the balance in research shifts decisively away from government laboratories and towards industry. Dr Weir agrees that the present assistance programmes are not a powerful tool, and he suspects that they influence companies only in borderline cases. But old habits die hard, and there is some reluctance to go over to a system of 100 per cent research contracting for civil work. 